\title{
Adrian P. Tudor, Erémitisme et solitude dans la première "Vie des Pères"
}

\section{Maria Colombo Timelli}

\section{(2) OpenEdition}

\section{Journals}

Édition électronique

URL : http://journals.openedition.org/studifrancesi/9786

DOI : 10.4000/studifrancesi.9786

ISSN : 2427-5856

Éditeur

Rosenberg \& Sellier

\section{Édition imprimée}

Date de publication : 1 octobre 2007

Pagination : 418

ISSN : 0039-2944

\section{Référence électronique}

Maria Colombo Timelli, «Adrian P. Tudor, Erémitisme et solitude dans la première "Vie des Pères" », Studi Francesi [En ligne], 152 (LI | II) | 2007, mis en ligne le 30 novembre 2015, consulté le 09 janvier 2021. URL : http://journals.openedition.org/studifrancesi/9786; DOI : https://doi.org/10.4000/studifrancesi. 9786

Ce document a été généré automatiquement le 9 janvier 2021.

\section{(c) (†) $\ominus$}

Studi Francesi è distribuita con Licenza Creative Commons Attribuzione - Non commerciale - Non opere derivate 4.0 Internazionale. 


\title{
Adrian P. Tudor, Erémitisme et solitude dans la première "Vie des Pères"
}

\author{
Maria Colombo Timelli
}

\section{RÉFÉRENCE}

ADRIAN P. TUDOR, Erémitisme et solitude dans la première "Vie des Pères", «Le Moyen Âge», CXII, 1, 2006, pp. 43-61.

1 Les ermites - reclus, cénobites, anachorètes - abondent dans la première Vie des Pères, recueil de contes pieux (premier tiers du XIII siècle) auquel Adrian P. Tudor a consacré une importante étude (Tales of Vice and Virtue. The First Old French "Vie des Pères", Amsterdam - New York, NY, Rodopi, 2005: cf. «SF», 151, 2006, pp. 159-160). Pratiquant l'ascèse, la prière, l'abstinence, les ermites donnent dans l'ensemble une image très positive d'eux-mêmes et de la vie contemplative. Cependant, comme le montre A.P. Tudor par l'analyse de deux de ces contes (Nièce et Le Prévôt d'Aquiléé), la solitude n'est pas une valeur en soi pour l'auteur du recueil: son but est plutôt de prêcher la confession, souligner l'importance de la charité, et montrer comment il est possible de concilier le bonheur dans le siècle et le salut spirituel. 